\title{
Hubungan antara Pengetahuan Lingkungan Hidup dengan Tingkat Kepedulian Warga Dalam Pengolahan Sampah di Bank Sampah Nusa Indah Raya
}

\author{
Muhammad Saiful Bahri ${ }^{1, *}$, Meitiyani ${ }^{1}$, Yuni Astuti ${ }^{1}$ \\ ${ }^{1}$ Pendidikan Biologi, Universitas Muhammadiyah Prof. DR. HAMKA, Pasar Rebo, Jakarta Tiimur, Indonesia \\ *Email: muhamadsaifulb@gmail.com
}

Received: 10 Oktober 2017| Accepted: 19 November 2017| Published: 25 Desember 2017

\begin{abstract}
ABSTRAK
Penelitian ini bertujuan untuk mengetahui hubungan antara pengetahuan lingkungan hidup dengan tingkat kepedulian warga dalam pengolahan sampah di Bank Sampah Nusa Indah Raya. Tempat penelitian di Kelurahan Cipondoh Komplek P dan K Kota Tangerang Provinsi Banten. Penelitian dilakukan pada bulan Maret hingga Oktober 2015. Populasi penelitian ini adalah seluruh warga RW. 05 Kelurahan Cipondoh. Sedangkan sampel adalah nasabah yang terdiri dari pengurus dan anggota Bank Sampah RW. 05 yang ditentukan dengan teknik purposive sampling. Penelitian ini termasuk penelitian deskriptif kuantitatif. Pengumpulan data diperoleh menggunakan instrumen berupa Tes dan Angket. Teknik analisis data yang digunakan adalah regresi linier, dilanjutkan dengan analisis korelasi sederhana dan koefisien determinasi. Hasil regresi linier memperoleh $\mathrm{F}_{\text {hitung }}=0.798<\mathrm{F}_{\text {tabel }}=2.41$ yang menunjukkan adanya hubungan yang linier dari dua variabel $X$ dan $Y$ dengan persamaan regresi $Y=73,756+0,142 X$. Hasil perhitungan koefisien korelasi diperoleh $\mathrm{r}_{\text {hitung }}=0,291<\mathrm{r}_{\text {tabel }}(5 \%)=0,374$ yang berarti $\mathrm{H}_{\mathrm{A}}$ ditolak. Dari hasil penelitian dapat disimpulkan bahwa tidak terdapat hubungan antara pengetahuan lingkungan hidup dengan tingkat kepedulian warga dalam pengolahan sampah di Bank Sampah Nusa Indah Raya. Kontribusi pengetahuan lingkungan hidup dengan tingkat kepedulian warga sebesar $8,46 \%$.
\end{abstract}

Kata kunci: Bank Sampah; Pengetahuan Lingkungan Hidup;Tingkat Kepedulian Warga

Copyright (C) 2017 BIOEDUSCIENCE All rights reserved

\section{PENDAHULUAN}

Manusia merupakan makhluk hidup yang memiliki kemampuan adaptasi dengan lingkungan baru melalui proses interaksi. Proses interaksi yang dilakukan baik secara biotik ataupun abiotik, menimbulkan suatu masalah baru di bidang lingkungan. Salah satu produk dari proses interaksi tersebut adalah sampah. Undang-Undang Nomor 18 Tahun 2008 tentang Pengolahan Sampah pasal (1) ayat mendefinisikan sampah adalah sisa kegiatan sehari-hari manusia dan/atau proses alam yang berbentuk padat. Kemudian dalam BAB VI tentang Penyelenggaraan Pengelolaan Sampah Pasal (20) poin b dan c yaitu pendauran ulang sampah; dan/atau pemanfaatan kembali sampah.

Salah satu daur ulang sampah dan pemanfaatan kembali yang dikenal di Indonesia adalah prinsip 3R (Reduce, Reuse, Recycle). Selain adanya prinsip $3 R$, pemerintah juga mempunyai program Bank Sampah. Bank Kementerian Lingkungan Hidup Republik Indonesia (2013) menjelaskan bahwa salah satu misi Bank Sampah yaitu merubah perilaku 
masyarakat dalam pengolahan sampah secara benar dan ramah lingkungan. Keberadaan Bank Sampah diharapkan kesadaran masyarakat tentang sampah, khususnya dalam pengolahan Bank Sampah meningkat sehingga masyarakat peduli terhadap lingkungannya dan program Bank Sampah dapat berjalan dengan baik.

Pemerintah daerah Kota Tangerang memiliki program Bank Central Sampah di dalamnya terdapat kegiatan pengelolaan Bank Sampah. Namun, pelaksanaan program Bank Central Sampah tidak berjalan baik seperti dijelaskan oleh Wakil Ketua II BCS Muhammad Rasyid dalam Harian Tangerang (2013), "Sebenarnya ada 300 Bank Sampah yang sudah dibangun, namun yang sudah berjalan secara optimal baru 158 saja". Berdasarkan hasil studi pendahuluan yang dilakukan Bahri (tidak dipublikasikan), Kelurahan Cipondoh RW. 05 Tangerang sudah memiliki Bank Sampah yang didirikan 2 (dua) tahun lamanya. Dari segi fisik, Bank Sampah mempunyai luas tanah yang cukup besar untuk menampung sampah dari tujuh RT di wilayah tersebut. Berdasarkan profil Bank Sampah yang diperoleh dari Kementerian Lingkungan Hidup, Bank Sampah komplek P \& K Kelurahan Cipondoh RW. 05 sudah memiliki kegiatan daur ulang sampah dan menghasilkan produk berupa kerajinan. Namun, berdasarkan temuan Bahri (tidak dipublikasikan) hal ini tidak sesuai dengan kondisi di lapangan. Salah satu pengurus Bank Sampah menyatakan bahwa, pelaksanaan Bank sampah belum berjalan dengan baik. Hal ini kemungkinan disebabkan oleh gengsi warga yang sangat tinggi sehingga kesadaran warga sangat kurang terhadap pengolahan sampah.

Berdasarkan latar belakang di atas, maka perlu dilakukan penelitian untuk mengetahui adakah hubungan antara pengetahuan lingkungan hidup dengan tingkat kepedulian warga dalam pengolahan sampah di Bank Sampah Nusa Indah Raya.

\section{MATERI DAN METODE}

Penelitian dilakukan di Kelurahan Cipondoh RW. 05 komplek $\mathrm{P}$ dan K Kota Tangerang Provinsi Banten, bulan Maret hingga Oktober 2015. Populasi merupakan penduduk RW. 05 Kelurahan Cipondoh yang terdiri dari tujuh RT. Sampel merupakan pengurus dan anggota Bank Sampah Nusa Indah Raya yang ditentukan dengan teknik purposive sampling. Metode yang digunakan deskriptif kuantitatif. Data diperoleh melalui tes pengetahuan lingkungan hidup dan Angket tingkat kepedulian masyarakat. Teknik analisis data menggunakan (1) uji linieritas merujuk pada (Nurgana, 1985), rumus sebagai berikut:

$$
F_{t c}=\frac{R K_{t c}}{R K_{k k}}
$$

Pengujian linieritas regresi bertujuan untuk mengetahui apakah variabel $\mathrm{X}$ dengan variabel $\mathrm{Y}$ memiliki pengaruh yang linier/searah atau tidak. Jika $\mathrm{F}_{\text {tc }}<\mathrm{F}_{\text {tabel }}$, maka regresi tersebut linier atau searah. Jika $F_{t c}>F_{\text {tabel }}$, maka regresi tersebut tidak linier atau tidak searah; (2) korelasi sederhana, rumus yang digunakan Pearson's Product moment Correlation (Susetyo, 2012).

$$
r=\frac{N \Sigma X Y-(\Sigma X)(\Sigma X)}{\sqrt{\left[N \Sigma x^{2}-(\Sigma X)^{2}\right]\left[N \Sigma Y^{2}-(\Sigma Y)^{2}\right]}}
$$

Keterangan :

Rxy = koefisien antara variabel $\mathrm{X}$ dan variabel $\mathrm{Y}$, dua variabel yang dikorelasikan

$\sum \mathrm{xy} \quad=$ jumlah perkalian $\mathrm{x}$ dengan $\mathrm{y}$

$\Sigma \mathrm{x} \quad=$ jumlah dari $\mathrm{x}$

$\Sigma \mathrm{y} \quad=$ jumlah dari $\mathrm{y}$

$\Sigma \mathrm{x}^{2} \quad=$ jumlah kuadrat dari $\mathrm{x}$

$\Sigma \mathrm{y}^{2}=$ jumlah kuadrat dari $\mathrm{y}$

$\mathrm{N} \quad=$ jumlah responden 
Analisis ini digunakan untuk mengetahui tingkat hubungan dan ada tidaknya hubungan antara pengetahuan lingkungan hidup dengan tingkat kepedulian warga dalam pengelolaan sampah di Bank Sampah Nusa Indah Raya. Jika $\mathrm{r}_{\text {hitung }}>\mathrm{r}_{\text {tabel }}$ maka $\mathrm{H}_{\mathrm{A}}$ diterima pada signifikansi 0,05 . Untuk mengetahui besar kontribusi yang diberikan dapat menguadratkan koefisien korelasi dan dikalikan 100\% (Susetyo, 2012).

\section{HASIL}

Hubungan antara pengetahuan lingkungan hidup dengan tingkat kepedulian masyarakat memperoleh persamaan regresi $\mathrm{Y}=73,756+$ $0,142 \mathrm{X}$.

Tabel 1. Hasil Linieritas Regresi

\begin{tabular}{ccccccc} 
SV & JK & db & RK & f & Kesimpulan \\
\cline { 1 - 4 } Tc & 496,45 & 11 & 45,13 & 0.798 & \\
\cline { 1 - 4 } kk & 961.46 & 17 & 56,55 & & Linier \\
\hline
\end{tabular}

Linieritas regresi memperoleh $\mathrm{F}_{\text {kritik }}$ sebesar 0.798 dan $\mathrm{F}_{0.99(11 / 17)}$ sebesar 2.41, sehingga $\mathrm{F}_{\text {kritik }}<$

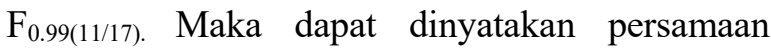
regresi $\mathrm{Y}=73.756+0.142 \mathrm{X}$ tersebut linier atau searah.

Berdasarkan persamaan regresi tersebut dapat diperoleh arah hubungan kedua variabel pada Gambar 1.

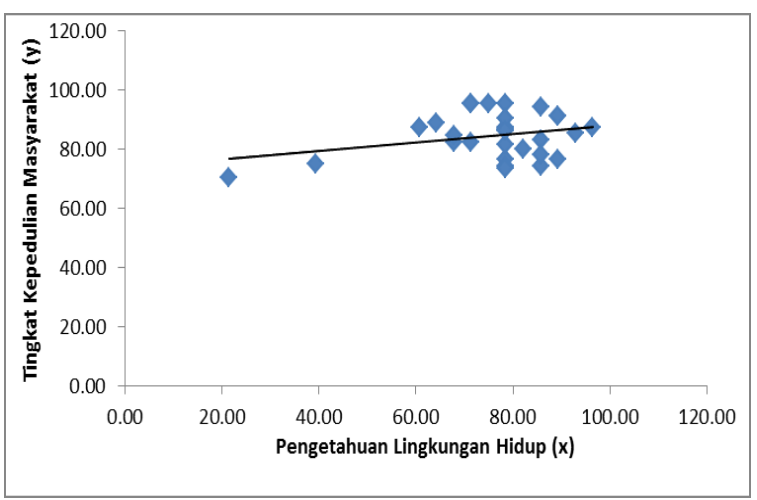

Gambar 1. Arah Hubungan Variabel
Terlihat bahwa sebaran data pada gambar di atas bisa dikatakan tersebar di sekeliling garis lurus. Beberapa terpencar dekat dengan garis lurus dan sisanya terpencar agak jauh dari garis lurus. Maka bisa dikatakan bahwa kedua variabel memiliki hubungan yang positif dan searah.

Tabel 2. Hasil Analisis Korelasi

\begin{tabular}{ccccc}
\hline Responden & df & rhitung & r tabel $(5 \%)$ & Kesimpulan \\
\hline $\begin{array}{c}\text { 30nasabah Bank } \\
\text { Sampah }\end{array}$ & 28 & 0,291 & 0,374 & Tidak ada hubungan \\
\hline
\end{tabular}

Dari tabel di atas diperoleh $\quad r_{\text {hitung }}=0,291$ $<\mathrm{r}_{\text {tabel }(5 \%)}=0,374$ dapat dikatakan $\mathrm{H}_{\mathrm{A}}$ ditolak. Artinya tidak terdapat hubungan antara pengetahuan lingkungan hidup dengan tingkat kepedulian warga dalam pengolahan sampah di Bank Sampah Nusa Indah Raya.

Kontribusi yang diberikan pengetahuan lingkungan dengan tingkat kepedulian warga sebesar $8,46 \%$.

\section{PEMBAHASAN}

Hasil analisis korelasi sederhana hubungan antara pengetahuan lingkungan hidup dengan tingkat kepedulian warga dalam pengolahan sampah di Bank Sampah Nusa Indah Raya memperoleh $\mathrm{r}$ (koefisien korelasi) 0,291, artinya kedua variabel mempunyai arah hubungan yang positif (semakin baik nilai pengetahuan lingkungan hidup, maka semakin baik juga tingkat kepedulian warga atau sebaliknya), tetapi hubungannya dapat digolongkan lemah. Namun berdasarkan perbandingan dengan $r_{\text {tabel }}, r_{\text {tabel }}$ memiliki nilai lebih besar dari $r_{\text {hitung }}(0,374>$ 0,291 ), artinya pengetahuan lingkungan hidup terhadap tingkat kepedulian warga dalam pengolahan sampah di Bank Sampah Nusa Indah Raya tidak terdapat hubungan.

Tidak terdapatnya hubungan antara pengetahuan lingkungan hidup dengan tingkat kepedulian warga dikarenakan minimnya pengetahuan yang diperoleh responden 
dikarenakan tidak adanya latar belakang lingkungan, tetapi responden merupakan nasabah atau anggota Bank Sampah sehingga mendapatkan pengetahuan bagaimana cara pengolahan sampah berdasarkan pengalaman langsung.

Menurut Setiyono ketua pengurus Bank Sampah RW. 05 menyatakan "bahwasanya selama dua tahun Bank Sampah berjalan tidak ada lagi penyuluhan terhadap pengelolaan Bank Sampah". Tidak adanya lagi penyuluhan yang dilakukan oleh pemerintah terkait pengelolaan Bank Sampah di RW. 05, menjadi salah satu faktor yang menyebabkan kurangnya minat masyarakat untuk peduli terhadap lingkungan khususnya pengelolaan Bank Sampah. Jahja (2011) menyatakan bahwa minat merupakan suatu dorongan yang menyebabkan terikatnya perhatian individu pada objek tertentu seperti pekerjaan, pelajaran, benda, dan orang.

Berkurangnya minat masyarakat akan mempengaruhi motivasi masyarakat dalam pengolahan Bank Sampah, karena minat merupakan sumber motivasi untuk melakukan apa yang diinginkan (Jahja, 2011). Terpengaruhnya motivasi berdampak terhadap tingkat kepedulian masyarakat dalam pengelolaan dan pengolahan Bank Sampah. Ameriana, dkk. (2006) dalam penelitiannya menjelaskan bahwa kepedulian konsumen dipengaruhi oleh faktor-faktor motivasi konsumen.

Selain dari faktor minat dan motivasi, faktor instrumen penelitian juga mempengaruhi hasil sehingga pengetahuan lingkungan hidup dengan tingkat kepedulian warga dalam pengolahan sampah di Bank Sampah Nusa Indah Raya tidak terdapat hubungan. Hal ini sesuai dengan pernyataan yang diberikan oleh ketua pengurus dari Bank Sampah RW. 05 Bapak Setiyono menyatakan "kalimat yang digunakan teralu sulit untuk masyarakat awam". Hal ini sesuai dengan observasi Bahri (tidak dipublikasikan) menjelaskan bahwasanya ada beberapa responden ketika mengisi kuesioner yang diberikan kebingungan dan banyak bertanya. Hal ini bisa terjadi karena responden bukan berlatar belakang pendidikan lingkungan hidup.

Berdasarkan fakta yang terjadi di lapangan tidak heran jika tingkat hubungan pengetahuan lingkungan hidup terhadap tingkat kepedulian lemah bahkan setelah dibandingkan dengan $r_{\text {tabel }}$ tidak terdapat hubungan antara pengetahuan lingkungan hidup terhadap tingkat kepedulian warga dalam pengolahan sampah di Bank Sampah Nusa Indah Raya. Hal ini juga sesuai dengan nilai kontribusi yang diberikan oleh pengetahuan lingkungan hidup dengan tingkat kepedulian masyarakat terlalu kecil sebesar $8,46 \%$ dan $91,54 \%$ kontribusi bisa diberikan melalui minat dan motivasi responden terhadap kepedulian dalam pengolahan sampah di Bank Sampah Nusa Indah Raya.

\section{KESIMPULAN}

Hubungan antara pengetahuan lingkungan hidup dengan tingkat kepedulian warga dalam pengolahan sampah di Bank Sampah Nusa Indah Raya tidak terdapat hubungan. Hasil penelitian tersebut dikhususkan untuk penelitian ini saja. Faktor terbesar dalam penelitian yaitu sulitnya warga memahami instrumen sehingga hasil hubungan antara pengetahuan lingkungan hidup dengan tingkat kepedulian warga dalam pengolahan sampah di Bank Sampah Nusa Indah Raya tidak terdapat hubungan.

\section{DAFTAR PUSTAKA}

Anonim. 2013. Pedoman 3R Melalui Bank Sampah. Kementerian Lingkungan Hidup RI.

Undang-undang Republik Indonesia Nomor 18 tentang Pengelolaan Sampah. 2008. Kementerian Lingkungan Hidup RI. 
BIOEDUSCIENCE 2017, Vol. 1, No. 1, pp. 01-05

Jahja, Y. 2011. Psikologi Perkembangan.

Prenadamedia. Jakarta.

Nurgana, E. 1985. Statistika Untuk Penelitian. CV.

Permadi. Bandung. 